\title{
Accessibility to Places of Evacuation for Inhabitants of Flood-Prone Areas in Mazovia Province
}

Abstract: This article attempts to map out accessibility to places of evacuation from flood-prone areas to the nearest and most-accessible public utility facilities within the boundaries of the Mazovia province of Poland with the use of the two-step floating catchment area method (2SFCA). A flood-prone area is defined as an area of the so-called 100-year water that was delineated on flood hazard maps. In order to accomplish the aim of the work, it was necessary to use data from the resources of the Topographic Objects Database (BDOT) and OpenStreetMap (OSM). It was concluded that the worst accessibility to places of evacuation within 15 minutes may be found in the southeastern part of the Mazovia province as well as along the Bug and Narew Rivers, which is where flood plains are wide and many residential buildings are located.

Key words: flood protection, evacuation, transport accessibility, Mazovia province, GIS, flood plains

* University of Lodz, Faculty of Geographical Sciences, Department of the Built Environment and Spatial Policy, Łódź, Poland

** "Spiru Haret" University, Faculty of Engineering, Informatics and Geography, Bucharest, Romania 


\section{Introduction}

Floods are considered one of the most dangerous and frequent natural disasters throughout the world. Not only do they generate huge financial losses, but they also represent a hazard to human life. There are many different types of floods as well as a multitude of diversified flood-protection measures. Potential financial losses increase due to the fact that flood hazard areas are becoming more and more developed, and people are putting too much faith in technical means of flood protection such as levees, reservoirs, etc. $[12,14]$. Floods cannot be completely eliminated, which is why societies need to learn how to live with them [13]. Methods of flood-loss reduction are included in the Flood Directive [5].

To reduce the extent of flooding and its adverse consequences, the following tasks (flood hazard and flood risk management) should be integrated [4]:

- prevention: preventing losses caused by floods through halting development in flood plains, especially in those places where it is economically justified, rethinking facilities that will be constructed for potential flood hazards, and fostering the appropriate use of land, (including agricultural and forest practices) so as to reduce the loss of natural soil retention;

- direct protection against flooding: undertaking technical and other measures in order to reduce the likelihood of occurrence and/or the impact of flooding in certain places;

- readiness: an adequate system of forecasts and warnings; i.e., notifying people about flood hazards and rules of conduct in the event of flooding;

- eEmergency proceedings: reacting to flooding; i.e., elaborating emergency plans in the event of flooding and anti-flood action;

- reinstating normal conditions and drawing conclusions: mitigating social and economic consequences in the cases of people affected by flooding.

There is, however, a fundamental difference between individual stages of flood risk management; i.e., flood protection or emergency proceedings. In the case of flood protection, its primary objective is the effective protection against the consequences of high water levels in such a way as to avoid the water directly contacting people and property. In turn, the aim of the emergency proceedings is to conduct an anti-flood action in the most-efficient manner rather than utilizing the protection understood as the modernization or construction of a protection system.

The anti-flood action consists of the following [4]:

- protecting human life and health as well as reducing the financial consequences of flooding during rescue operations;

- transport efficiency concerning the evacuation of people and property as well as providing materials and devices to reduce losses;

- securing damage-prone facilities and devices that may pose a threat to the environment during a flood, such as sewage systems, filling stations, or chemical plants; 
- securing public utility facilities in which there are many people;

- other activities tailored to the specificity of a given region.

This article focuses on only one aspect of reacting to a flood event: transport efficiency concerning the evacuation of people. Evacuation is understood here as moving people away from a (potentially) flood-prone area before there is direct contact of people with "water" and housing them in "safe" places until it is no longer necessary $[9,15]$. The degree of evacuation success depends on a number of factors, such as warning time, reaction time, dissemination of information and instructions on how to act during evacuation, evacuation routes, possibilities of traveling on roads, etc. [20].

The aim of this article is to map out the spatial differentiation of accessibility to places of evacuation from flood hazard areas to the closest and most-convenient public utility facilities within the Mazovia province. The research, therefore, was conducted on a regional scale [19].

\section{Research Area}

For detailed research, the authors selected the Mazovia province situated in the central-eastern part of Poland. It is the biggest province in the country (with an area of $35,600 \mathrm{~km}^{2}$ ). Its capital is Warsaw (which is also the capital of the country) with its $1.7 \mathrm{~m}$ inhabitants, whereas the whole region is populated by $5.2 \mathrm{~m}$ people [22]. The Mazovia province is comprised of 37 districts, 5 towns with county rights, and 314 communes.

Its settlement network is made up of 85 urban units, including the following breakdown [28] (Fig. 1):

- 1 city with more than 1,000,000 inhabitants (Warsaw);

- 2 cities with 100,000 to 250,000;

- 4 with 50,000-100,000;

- 13 with 25,000-50,000;

- 29 with 10,000-25,000;

- 36 with fewer than 10,000 inhabitants (as well as numerous villages).

The basic road network in the analyzed area is comprised of national and province roads; its layout is centralized, and most of the main routes meet at the capital [33] (Fig. 1).

The whole area of the province in question is situated in the Vistula basin in the water region of the central the Vistula River. Its basin is asymmetric, with prevailing right-bank tributaries; the longest of which is the Narew River. In turn, the longest tributaries of the Narew within the boundaries of the discussed area are the Bug, Wkra, and Orzyc Rivers. The longest left-bank tributaries of the Vistula (considering the size of catchment area surface) in the Mazovia province include the Radomka 
and Pilica Rivers [22] (Fig. 2). The area of 100-year water within the Mazovia province is 1,300 km² (Tab. 1), of which the largest is on the Vistula River (about $400 \mathrm{~km}^{2}$ ), the Narwia (about $300 \mathrm{~km}^{2}$ ), and the Bug (about $250 \mathrm{~km}^{2}$ ). In the event of flooding, as many as 136 communes (out of 314) may be inundated (Tab. 1). The largest surface of the flood plains can be found in the communes in the southern part of the Mazovia province; i.e., in Magnuszew, Maciejowice, and Kozienice. Within their boundaries, the Radomka, Pilica, and Zagożdżonka Rivers meet the Vistula, which is why the flood plains are very wide there; their surface in each of them amounts to between 50 and $60 \mathrm{~km}^{2}$ within area exposed to floods, where 15,131 residential buildings are located and 34,101 people live (Tab. 1).

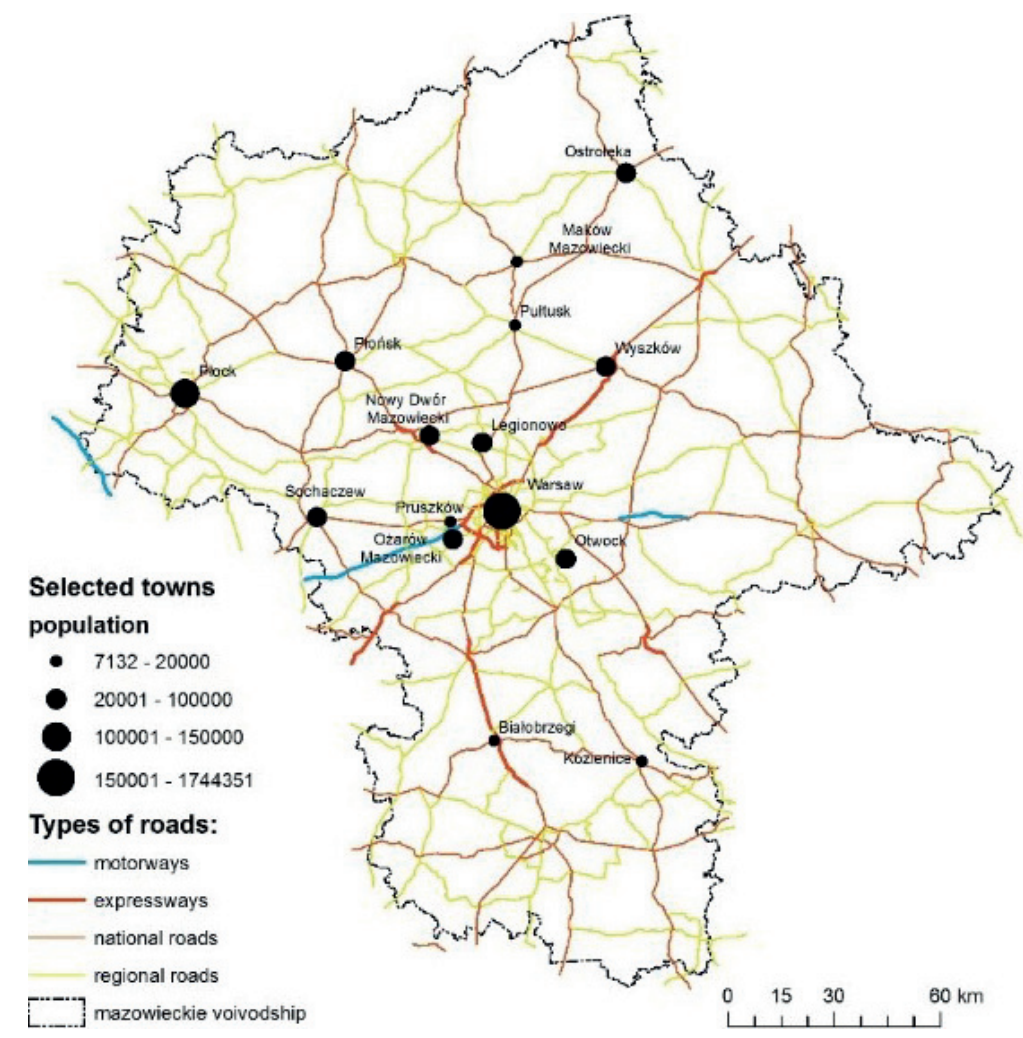

Fig. 1. Location of Warsaw in transport and settlement network of Mazovia province

Table 1. Statistical characteristics of 100-year flood zone

\begin{tabular}{|l|c|c|c|c|c||}
\cline { 2 - 6 } \multicolumn{1}{c|}{} & $\begin{array}{c}\text { Surface } \\
{\left[\mathrm{km}^{2}\right]}\end{array}$ & $\begin{array}{c}\text { Number of } \\
\text { settlement units }\end{array}$ & $\begin{array}{c}\text { Number of } \\
\text { inhabitants }\end{array}$ & $\begin{array}{c}\text { Number of residential } \\
\text { buildings }\end{array}$ & $\begin{array}{c}\text { Surface of residential } \\
\text { buildings [m²] }\end{array}$ \\
\hline $\begin{array}{l}\text { 100-year } \\
\text { flood zone }\end{array}$ & 1315 & 164 & $1,642,126$ & 15,131 & $1,224,574.5$ \\
\hline
\end{tabular}


The largest number of residential buildings are situated in places where the flood plain is the greatest (where the river is joined by its tributaries): the upper section of the Vistula within the Mazovia province along with the middle sections of the Bug and Narew. Moreover, residential development can be found along smaller rivers in the region, such as the Pilica, Radomka, Wkra, and Bzura Rivers (Figs. 2, 3).

Warsaw was classified in $12^{\text {th }}$ position considering the size of the flood plains in the communes of the Mazovia province. The so-called 100-year flood zone occupies about $25 \mathrm{~km}^{2}$ in the capital (the risk level was also described as very high there). The Vistula River flows through the very center of the city, dividing it into two parts: the left bank and right bank. Larger flood-prone cities in the Mazovia province (outside Warsaw) include the following: Płock (with 122,000 inhabitants), Pruszków, Legionowo, Ostrołęka, and Otwock (40,000-60,000 inhabitants), and Sochaczew, Nowy Dwór Mazowiecki, Wyszków, and Płońsk (20,000-40,000 inhabitants) (Figs. 1, 2).

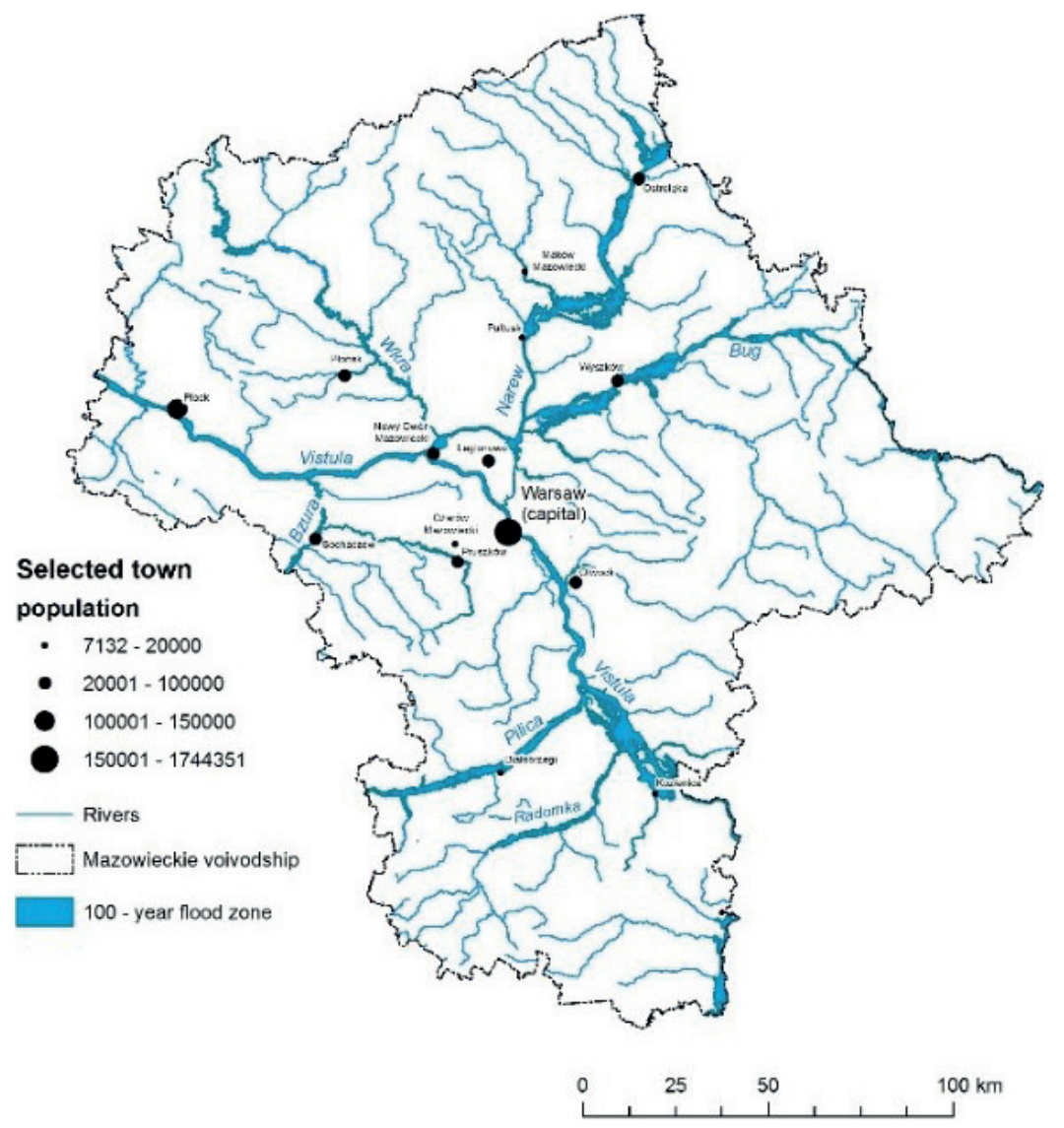

Fig. 2. Rivers and flood hazard areas in Warsaw region Source: own study based on [34] 


\section{Source Materials and Research Methods}

This article concentrates on one element of flood-hazard management: the evacuation of people. It was assumed that, in the Mazovia province, there will be a flood with a probability $p=1 \%$ (the areas of the so-called 100-year water). These areas were delineated on flood-hazard maps, which was one of the stages of the Flood Directive implementation by the EU member states [29, 30]. Flood-hazard maps show areas of different probabilities of flooding; yet, due to the fact that researchers most-frequently use the areas of the so-called 100 -year water $\left(Q_{p}=1 \%\right.$; i.e., discharge of probability of occurrence $p=1 \%$ ), the researchers also decided to limit themselves to their scope $[2,3,8]$. The area was divided into primary fields $(174,816)$ of a square shape with sides of $100 \mathrm{~m}$, which was connected with the features of the spatial distribution of residential development exposed to the flood hazard. As it is distributed in "islands", the obtained results would also allow us to assess accessibility levels only to the areas of these "islands", and the aim of the research was to map out the differentiation of accessibility levels for the whole flood-hazard area. Moreover, the use of artificial primary fields allows us to show levels of accessibility to places of evacuation on the areas where development may occur in the future.

The number of both one- and multi-family residential buildings was calculated within each primary field. The potential number of people living in the analyzed area was estimated on the basis of the number and types of residential buildings as well as their surface (which was multiplied by the number of stories in each building). In order to obtain the highest-possible accuracy while establishing the number of inhabitants of a given building, estimations were made on the level of the commune. Using the Local Data Bank of the Main Statistical Office (BDL GUS), the authors obtained data on the number of inhabitants in each basic territorial unit. Subsequently, the number and surface of residential buildings was calculated on the basis of the Topographic Objects Database (BDOT) for each commune. The quotient of these two values allowed us to determine how many people there are in each commune for each $1 \mathrm{~m}^{2}$ of residential building surface in each of the basic units in the Mazovia province (Fig. 3).

Then, the authors identified public utility facilities in the Mazovia province to which people can be evacuated. To accelerate the research, further deeper analyses included only those located within 15-minute travel isochrones from the boundary of the so-called 100-year water. They are comprised of churches, schools, research institutions, physical education buildings, cultural institutions available to the general public, hospitals, and healthcare centers. Buildings with their functions, numbers of stories, and types of development were also taken from the resources of the Topographic Objects Database (BDOT) obtained from the Provincial Center of Geodetic and Cartographic Documentation in Warsaw. The adopted research accuracy, together with the assumed regional scale of the research, allows us to determine the adjustment of distribution and the size of potential places of evacuation for the distribution of the region's population. 
Travel time of the fire brigades to the place of an event has a direct impact on saving human life and health as well as the effectiveness of the activities carried out during rescue operations [11]. According to the Regulation of the Minister of Internal Affairs and Administration of 18 February 2011, all entities located outside of the city, municipality, or county incorporated into the National Rescue and Fire Fighting System carry out basic salvage operations in their area of activities referred to commuting times: 8 and 15 minutes. When units of the State Fire Services are not able to reach within a 15-minute drive of the first forces and means to place an event (in this case, the objects located on floodplains) should be provided by units of the Volunteer Fire Brigade [7]. Therefore, the authors decided to perform their analysis for within 15 minutes.

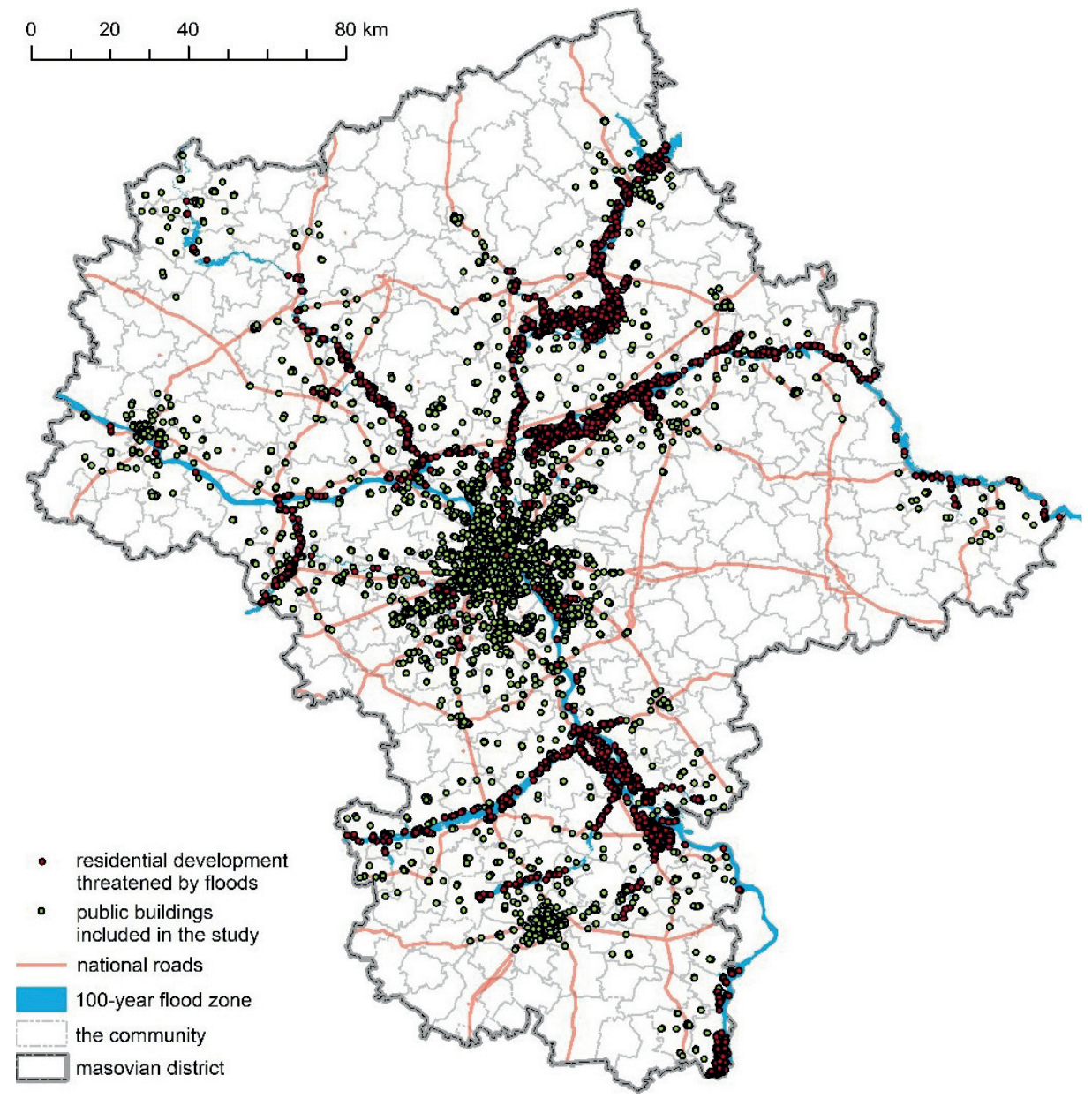

Fig. 3. Distribution of residential buildings in flood-prone areas and public utility facilities located in "safe" areas of Mazovia province 
In turn, information regarding the potential route and allowed maximum speeds on individual road network sections was obtained from the resources of the General Directorate for National Roads and Motorways (GDDKiA), the Mazovia Province Roads Authority, as well as OpenStreetMap (OSM) databases. The latter project was launched in 2004, and it is one of the biggest free editable sources of geographic information [16,17]. Additional data included in this resource has attributes ascribed to them; in the case of roads, this is data on their categories, maximum permissible speeds, etc. [18].

In order to accomplish the research aim, the two-step floating catchment area method (2SFCA) was used in a modified version so as to capture the gist of the research in the best-possible way. This is one of numerous methodological approaches used in research into accessibility. Spatial accessibility is a research topic that is frequently discussed, especially in the field of geography. The literature devoted to this topic is rather vast, both as related in publications from Poland and elsewhere. Clear intensification of the research into accessibility is connected with analyses conducted by the Stanisław Leszczycki Institute of Geography and Spatial Organization of the Polish Academy of Sciences in Warsaw. This group of literature includes, among other publications, a book by R. Domański [6], which is an introduction into the topic of accessibility (also from the transport perspective). Preliminary issues concerning transport accessibility analysis may also be found in texts by K. Warakomska [31] and W. Sobczyk [26]. The issues of accessibility measurements are also raised by S. Baradaran and F. Ramjerdi [1]. Similarly, publications by P. Rosik (for instance, from 2008 and 2012) [23, 24] are invaluable for research into accessibility. Publications by T. Komornicki and others [10] on the relationship between spatial accessibility and transport policy, or those by W. Pietrusiewicz [21], M. Stępniak [27], or P. Śleszyński [25] comprise an equally vast source of information on notions concerning transport accessibility and the methods used to measure it.

The analysis uses the time scope of traveling from flood-prone areas of residence to places of potential evacuation that do not exceed 15 minutes. The choice of the interval was preceded by a repeated simulation of research with different values of travel time. Even though it is not supported by objective research, the value adopted in the end seems to best reflect the scale. The distance between each analyzed flood-prone building and individual places of evacuation is expressed in units of travel time by passenger car. It is assumed that changes in travel time by car during evacuation are affected solely by traffic regulations referring to maximum permissible speeds. Despite the fact that drivers may not obey speed limits during an evacuation, it may be alleged that project speeds determine the maximum speed that allows drivers to reach a "safe" place in a secure way. In this way, the authors excluded all other factors such as road congestion or weather conditions. A car moves on the shortest path between two points. Each section of the road network was given attributes in the form of length and permissible speed. 
Considering that drivers will likely utilize on every type of transport infrastructure during an evacuation, our analysis also considers footpaths or foot and vehicle paths. This is the basis on which the travel time of each section was calculated. This allowed us to select subsequent sections of the network that would ensure the shortest total travel time between the starting point and the destination (Dijkstra's algorithm).

All of the elements of cartography that were included in this article as well as the associated calculations and analyzes were performed using ArcMap software.

In the first part of the two-step floating catchment area method, the area accessible from each potential place of evacuation is mapped out, assuming 15 minutes as the maximum travel time. Subsequently, for each public utility building, the authors calculate individual indicator $R_{i}$ being the quotient of weight (surface of building) of individual buildings to the number of people living in flood-prone buildings in the area delineated by the given isochrone of travel from the concrete place of evacuation [32]:

$$
R_{j}=\frac{S_{j}}{\sum_{i \in\left\{d_{i j} \leq d_{\max }\right\}} \sum P_{p i}}
$$

where:

$$
\begin{aligned}
& S_{j}-\text { weight (surface) of potential place of evacuation } j, \\
& P_{p i}-\text { number of inhabitants of a residential building exposed to flood haz- } \\
& \text { ard } p \text { in research field } i \text {, } \\
& d_{i j} \text { - travel time between potential place of evacuation } j \text { and centroid of re- } \\
& \text { search field } i \text {, } \\
& d_{\max } \text { - isochrone delineating maximum travel time by passenger car (15 min- } \\
& \text { utes). }
\end{aligned}
$$

In this way, the theoretical load of individual places of evacuation is calculated for the Mazovia province. In the second part of the two-step floating catchment area method, attention shifts to research fields within whose boundaries residential development is located from which evacuation may take place. For each centroid of primary field $i$, an area is delineated as it was in the first stage of the analysis with the use of the adopted border value of travel time. Then, for each field $i$ included into the research, the authors estimated accessibility indicator $A_{i}$, which is the sum of value $R_{i}$ obtained for all places of potential evacuation distributed on the area of individual field surface [32]:

$$
A_{i}=\sum_{j \in\left\{d_{i j} \leq d_{\max }\right\}} R_{j}
$$


The numerical results of accessibility to potential evacuation places from individual primary fields within flood-prone areas were transformed into a five-step descriptive scale (very low, low, average, high, and very high accessibility) in order to facilitate the reception and interpretation of the results. The average value of accessibility levels and the standard deviation of this variable were defined for individual variants of the research (travel distance to the stop/node). Therefore, the boundaries of class ranges represent multiplications of the standard deviation added to or subtracted from the average, depending on whether the accessibility is above or below the average (e.g., very low accessibility is the level of accessibility not higher than the average reduced by three times the standard deviation).

\section{Results}

Carrying out the research proceedings allowed us to determine the number of flood-prone residential buildings (numbering 151,131). Their surface is $1,224,574.5 \mathrm{~m}^{2}$ in total in accordance with the building's outline, but this number increases to $1,838,351.3 \mathrm{~m}^{2}$ if other stories are considered. Having adopted the above assumptions of estimating the extent of the population, it was established that these buildings are inhabited by 34,101 people.

After drawing an isoline of identical travel time to flood-prone areas at a value of 15 minutes, it was also possible to determine the number of public utility buildings representing potential places of evacuation: 8,257 . This amounts to a total of $6,250,588.5 \mathrm{~m}^{2}$ on the ground floor and as much as $14,707,316 \mathrm{~m}^{2}$ after summing up the remaining stories.

An especially alarming situation concerns 1,593 flood-prone residential buildings whose inhabitants are incapable of reaching any facility that could provide them with shelter within 15 minutes (Fig. 4). These are buildings located mostly on the area of communes in the northeastern part of the province (such as Obryte, Rzewnie, or Dąbrówka) as well as in the southeastern part (in places like Maciejowice or Kozienice) (Fig. 4).

Acting in accordance with the assumptions of the first part of the two-step floating catchment area method, the authors analyzed the impact of the interrelated distribution of residential development and public utility facilities against the background of the region's road network on the possible "load" of potential places of evacuation of the population from flood-prone areas. In the first place, the load in absolute terms was referred to the number of potentially evacuated people who are capable of reaching a "safe" public utility facility from their home in 15 minutes (Fig. 5). The markedly largest group of people may reach facilities located in the southeastern and central parts of the region. 


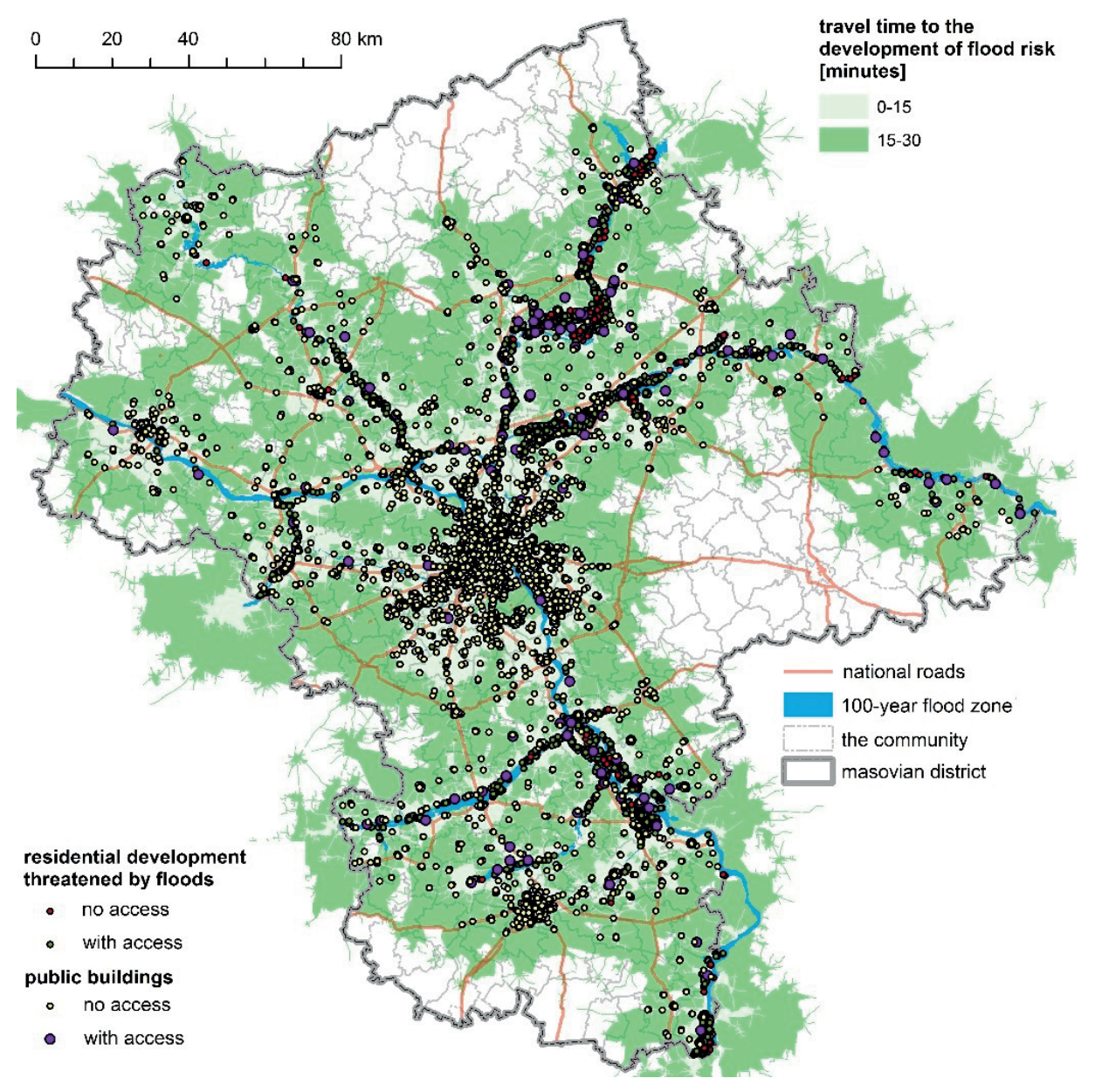

Fig. 4. Spatial differentiation of time transport accessibility of residential buildings located on flood plains in Mazovia province

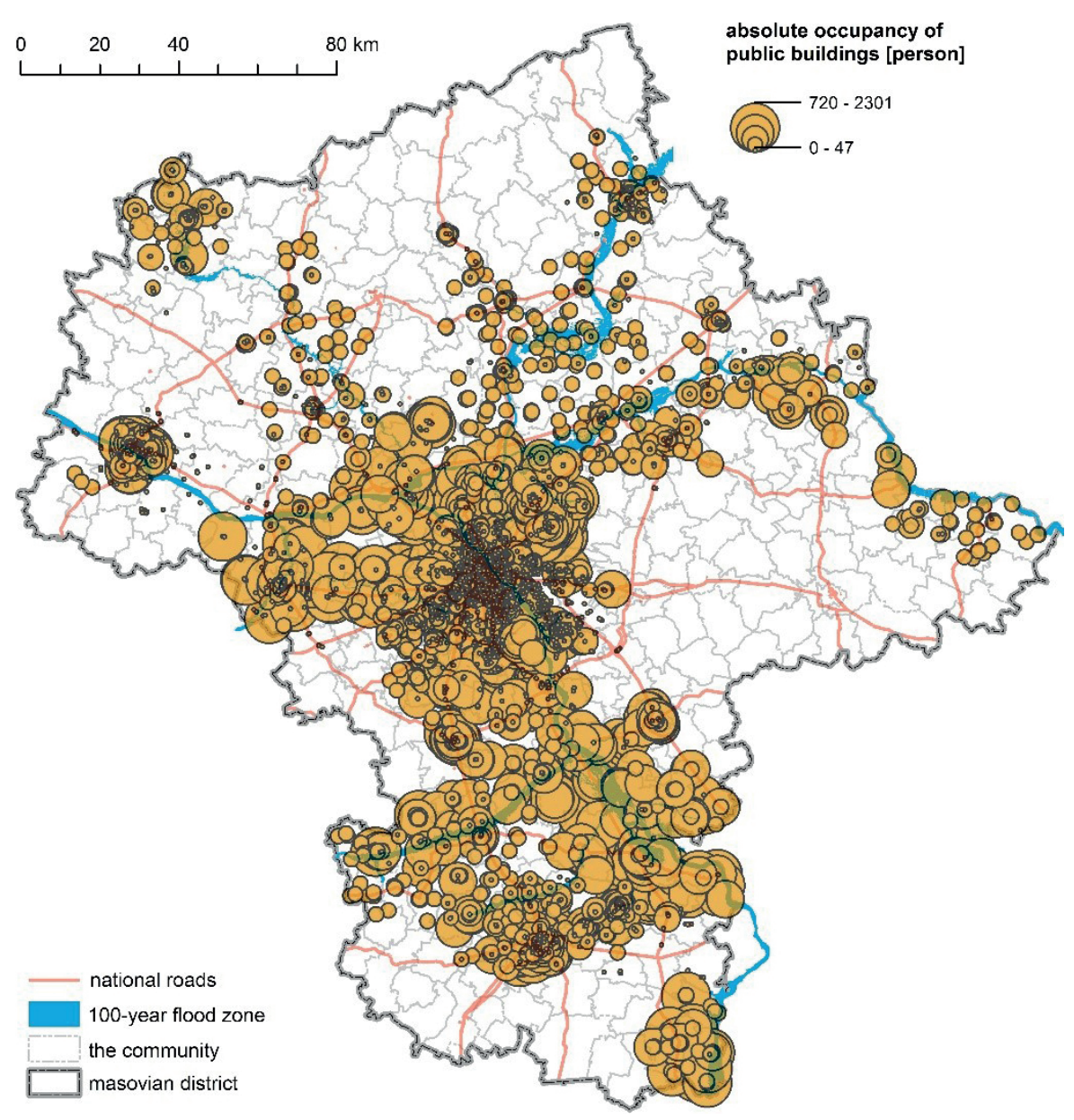

Fig. 5. Spatial differentiation of absolute load of potential evacuation towns (public utility facilities) in Mazovia province 


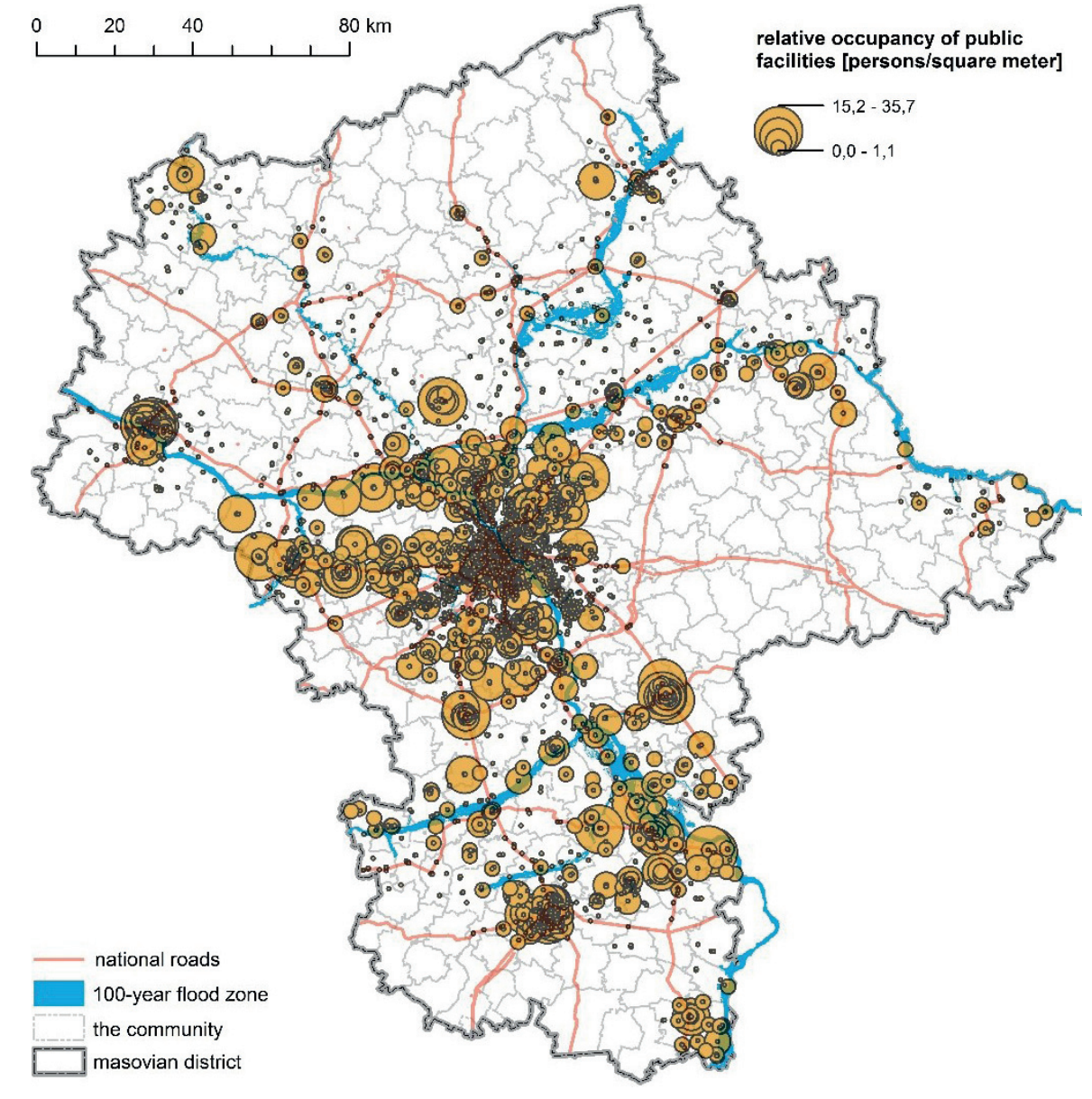

Fig. 6. Spatial differentiation of relative load of potential evacuation towns (public utility facilities) in Mazovia province

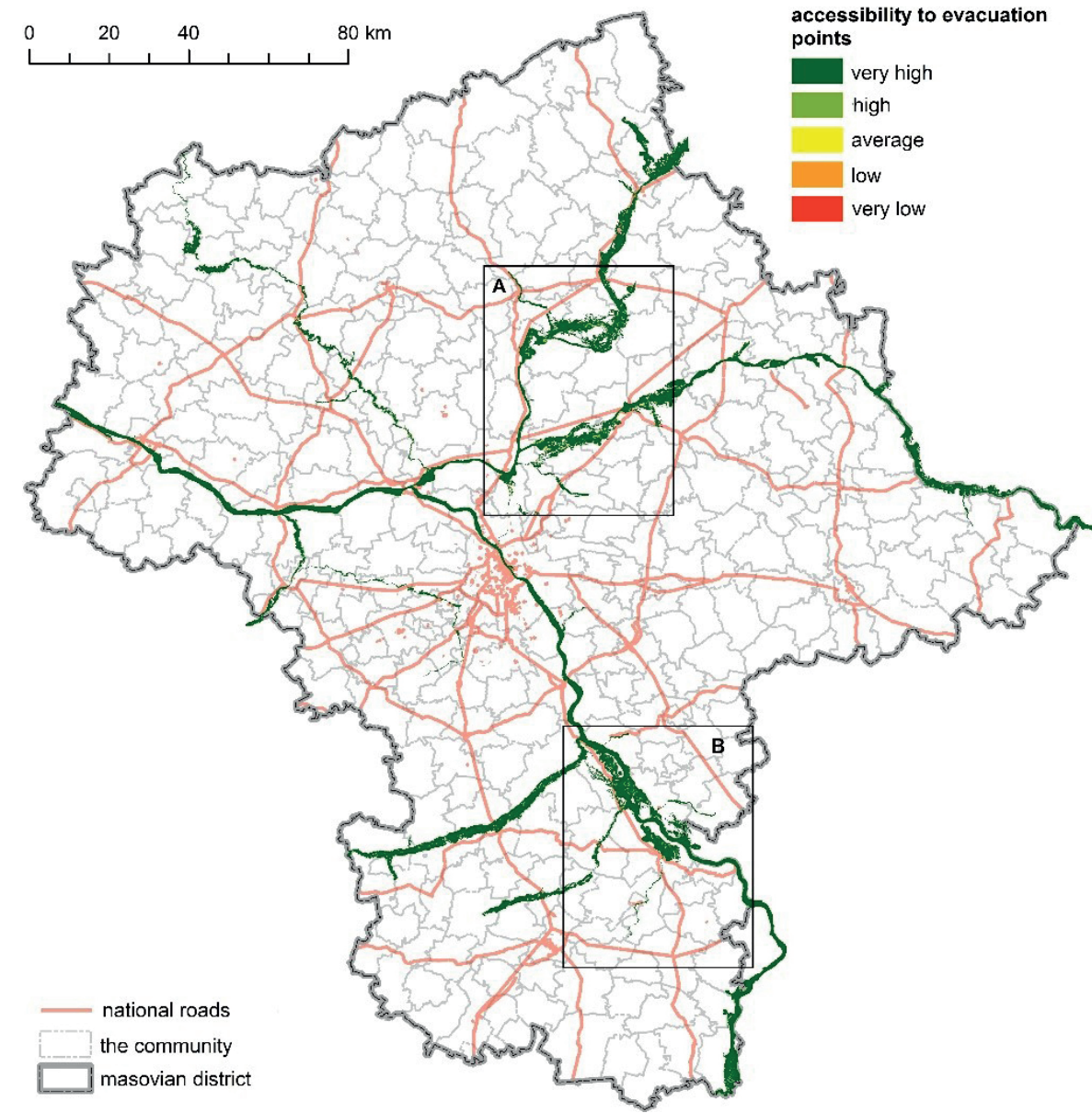

Fig. 7. Spatial differentiation of accessibility levels to potential places of evacuation (public utility facilities) in Mazovia province 
If Warsaw and its immediate vicinity are characterized by a large number of potential places of evacuation, they still remain unused in the majority of cases, since there is no flood-prone residential development from which evacuation could be effected in their vicinity. These resources, however, are so large and well-connected with the territory of the province that they may become invaluable in the case of evacuation that allows for travel time longer than 15 minutes. In turn, there are many residential buildings on the Bug and Narew Rivers; however, due to the large number of public utility facilities in their vicinity, their load is rather small.

The existence of a potential place of evacuation does not fully reflect the safety level of a given area. A much-truer picture of reality is conveyed by analysis concerning the extent to which such facilities are accessible to flood victims, as they may reach the given place of evacuation in the assumed time yet will not find shelter there due to overcrowding. This is why it was decided that the load of facilities will also be defined in relative terms (Fig. 6), which specifies how many victims there are in theory per unit of space of a facility allocated to provide such shelter.

This approach points to an especially disturbing situation in the southeastern part of the region, where there are many residential buildings in flood-prone areas, and the size of the facilities available to potential victims seems rather disproportionate.

Exclusion of results in the relative form from further calculations connected with the 2SFCA brought the answer concerning the shape of the spatial differentiation of inhabitants in flood-prone areas to places of evacuation (Fig. 7). In general, it should be concluded that the larger part of the so-called 100-year water areas are characterized by very good conditions as far as potential evacuation is concerned. Due to the high degree of narrowing down the research (i.e., introduction of the primary field of $1 \mathrm{ha}$ ), two areas were revealed (Figs. 8, 9) that, in the event of flooding, should remain under observation of those services responsible for crisis management.

The first of them (A) comprises a fragment of flood-prone areas situated along the Bug and Narew Rivers (Fig. 8), whereas the latter (B) are areas located in the upper section of the Vistula within the boundaries of the Mazovia province, together with the Radomka River (Fig. 9). Fragments of flood plains in the communes south of Zegrze Lake (i.e., Nieporęt and Marki) are characterized by average, low, and very low accessibility to places of evacuation. A similarly unfavorable situation can be found along the Bug, and it refers to flood plains in the communes of Łochów, Brańszczyk, Wyszków, Zabrodzie, Somianka, and Dąbrówka. In turn, along the Narew River, average accessibility can be found in some areas of the so-called 100-year water in the communes of Olszewo-Borki, Młynarze, Gaworowo, Długosiodło, Rzewnie, Rząśnik, Obryte, and Pułtusk (Fig. 8).

Besides this, fragments of flood plains located in the communes of Kozienice and Maciejowice have average (and even low and very low accessibility in some areas) in those places where there are the greatest number of residential buildings along with too-few facilities to which inhabitants could be potentially evacuated (Fig. 9). 


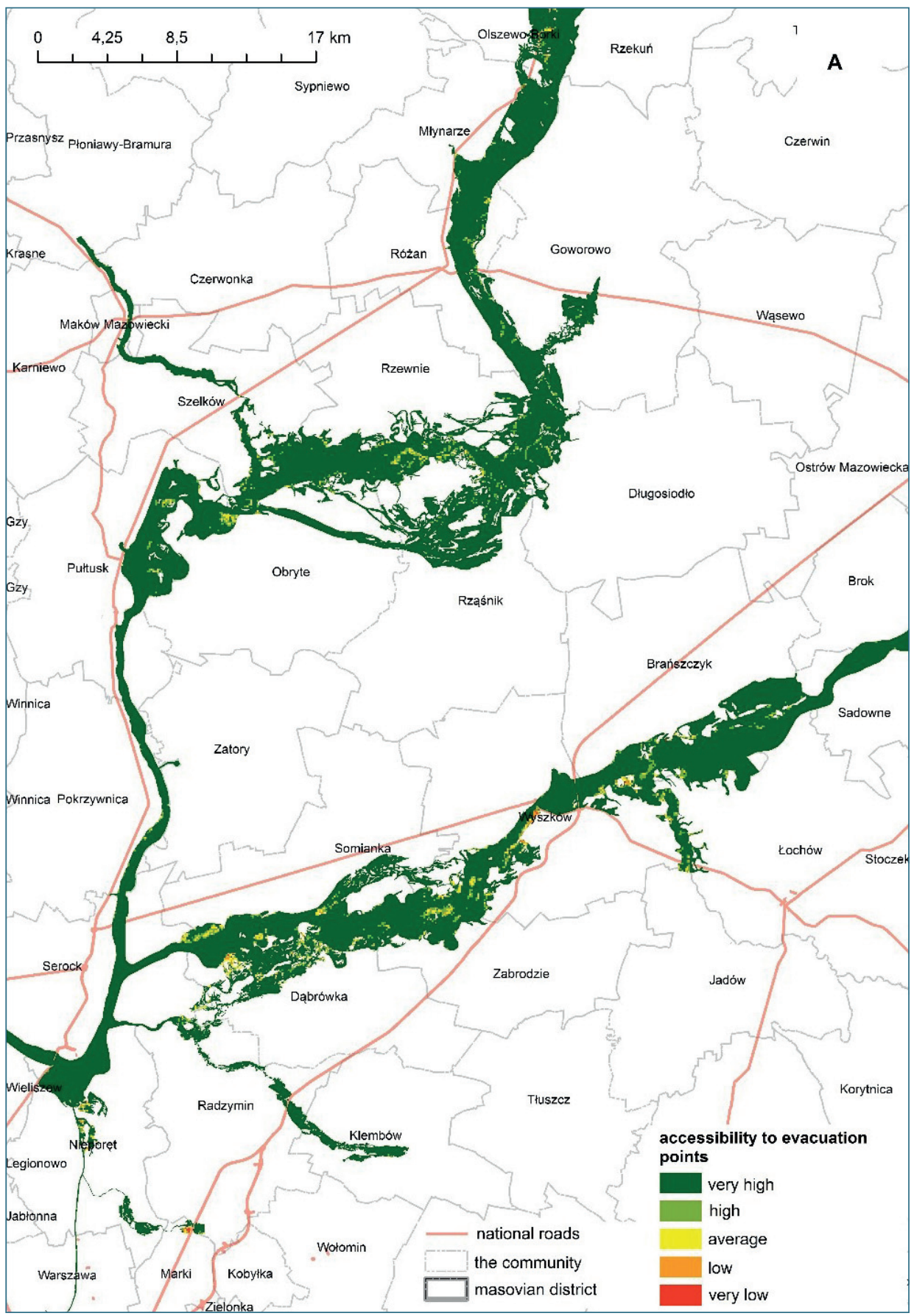

Fig. 8. Spatial differentiation of accessibility levels to potential places of evacuation (public utility facilities) for Area A 


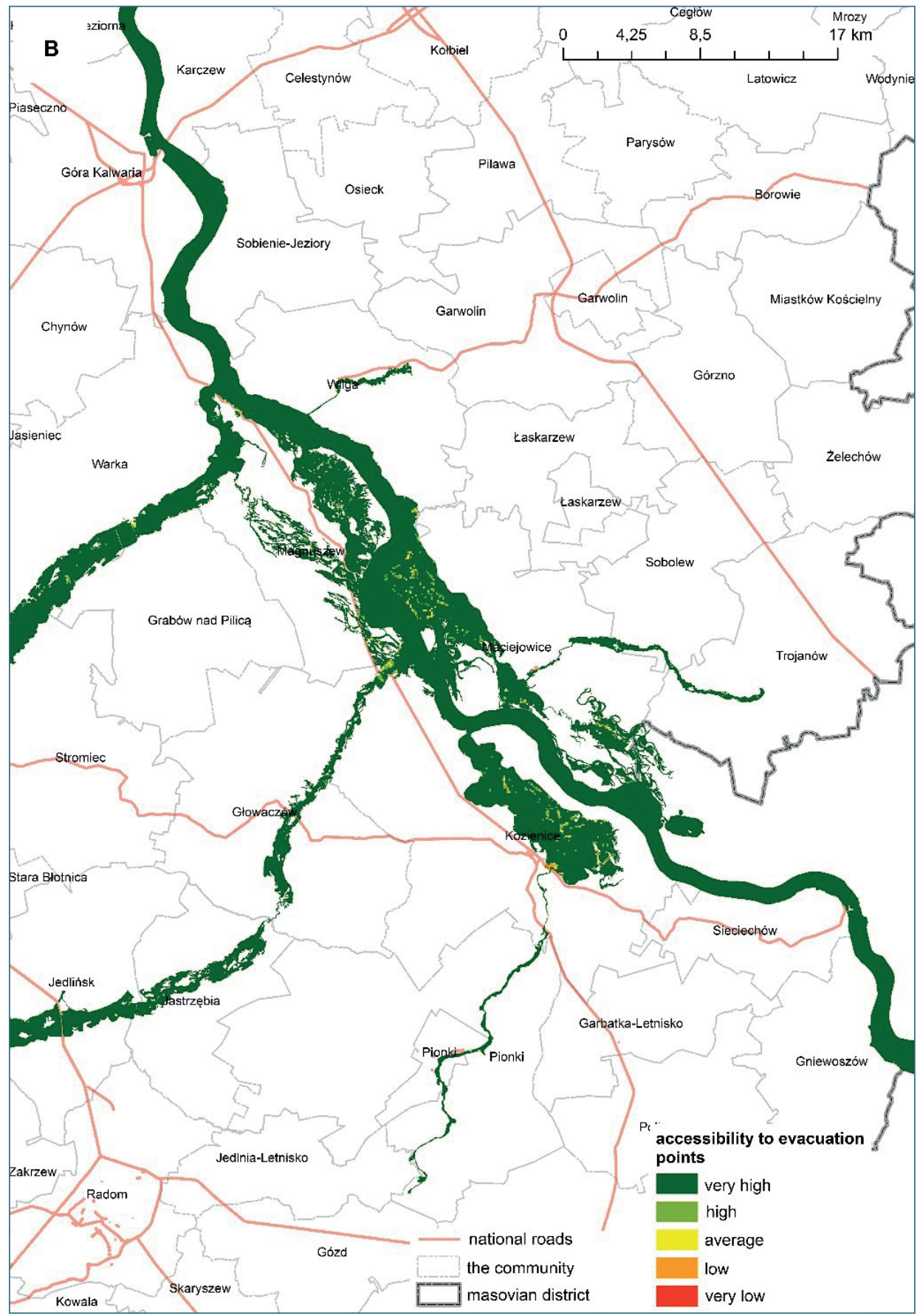

Fig. 9. Spatial differentiation of accessibility levels to potential places of evacuation (public utility facilities) for Area B 


\section{Conclusions}

In order to reduce the extent of flooding and its consequences, tasks (flood hazard and flood-risk management) should be integrated to include prevention, direct protection against flood, readiness, emergency proceedings, reinstating normal conditions, and drawing conclusions. These are activities that are performed at a different time: both before and after a flood event. It should be remembered, however, that each element of flood risk management is of paramount importance in minimizing losses. The literature rarely addresses the issues of one of these elements; namely, reacting to a flood. This is why the authors made an attempt to map out the accessibility to places of evacuation from flood-prone areas to the nearest and most-accessible public utility facilities within the boundaries of the Mazovia province. In the aftermath of the conducted analyses, it was concluded that the worst situation concerning accessibility to places of evacuation within 15 minutes can be found in the southeastern part of the Mazovia province, with flood plains along the Vistula and its tributaries (such as the Radomka). It is precisely there that the flood plains are the widest, which is why the inhabitants are willing to situate residential buildings there. A similar situation refers to the flood plains of the Bug and Narew Rivers.

The theoretical approach of the process of population evacuation from flood-prone areas on the spatial plane may represent diagnostic material for possible activities aimed at increasing the effectiveness of the present system of services operating within crisis management or the implementation of technological, legal, administrative, or informative solutions to the indicated problematic areas that might prevent or minimize possible losses. The research carried out to a large extent theorizes the multi-faceted activities of the evacuation process and may serve only as a basis for further deepened research. It seems advisable to compare the results of this analysis with an analysis of the distribution of real evacuation paths, their types, duration times, or effectiveness. Such deepened research is particularly recommended for those communes that obtained the lowest accessibility levels and have a large number of residential buildings within the flood plains. It also seems invaluable to conduct a separate analysis aimed at comparing the obtained results referring to individual research planes on the commune level and the level of transport accessibility from a synthetic standpoint.

\section{References}

[1] Baradaran S., Ramjerdi F.: Performance of Accessibility Measures in Europe. Journal of Transportation and Statistics, vol. 4, no. 23, 2001, pp. 31-48.

[2] Borowska-Stefańska M.: Flood risk assessment of Łódź province communes. Humanities and Social Sciences, vol. 20 (22), 2015, pp. 9-23. 
[3] Borowska-Stefańska M.: Zagospodarowanie terenów zagrożonych powodziami w województwie łódzkim. Wyd. UŁ, Łódź 2015,

[4] Buczek A., Nachlik E.: Wykorzystanie BDOT w ocenie ryzyka powodziowego problemy integracji informacji przestrzennej. Roczniki Geomatyki, t. 9, z. 6(50), 2011, pp. 77-87.

[5] Directive 2007/60/EC of the European Parliament and of the Council of 23 October 2007 on the assessment and management of flood risks.

[6] Domański R.: Accessibility, Efficiency and Spatial Organization. Environment, and Planning A, vol. 11, issue 10, 1979, pp. 1189-1206.

[7] Drzymała T., Krawczyńska S., Gałaj J.: Badanie wpływu różnych czynników na czas dojazdu samochodów ratowniczo-gaśniczych z siedziby jednostki PSP na miejsce akcji. Logistyka, nr 4, 2014, pp. 230-237.

[8] Gutry-Korycka M., Magnuszewski A., Suchożebrski J., Jaworski W., Marcinkowski M., Szydłowski M.: Numerical estimation of flood zones in the Vistula River valley, Warsaw, Poland. [in:] Climate Variability and Change-Hydrological Impacts (Proceedings of the Fifth FRIEND World Conference held at Havana, Cuba, November 2006), IAHS Publ. 308, IAHS International Commission on Water Resources Systems, 2006, pp. 191-195.

[9] Jonkman S.N., Vrijling J.K., Vrouwenvelder A.C.W.M.: Metohods for the estimation of loss of life due to floods: a literature review and a proposal for a new method. Natural Hazards, vol. 46, 2008, pp. 353-389.

[10] Komornicki T., Śleszyński P., Rosik P., Pomianowski W.: Dostępność przestrzenna jako przesłanka kształtowania polskiej polityki transportowej. Biuletyn KPZK PAN, z. 241, Warszawa 2009.

[11] Krawczyńska S., Drzymała T., Gałaj J.: Badanie wpływu różnych czynników na czas interwencji jednostek PSP w czasie działań ratowniczo-gaśniczych. Logistyka, nr 5, 2014, pp. 832-841.

[12] Kundzewicz Z.W., Takeuchi K.: Flood protection and management: quo vadimus? Hydrological Sciences Journal, vol. 44, issue 3, 1999, pp. 417-432.

[13] Kundzewicz Z.W.: Flood protection - sustainability issues. Hydrological Sciences Journal, vol. 44(4), 1999, pp. 559-571.

[14] Kundzewicz Z.W.: Non-structural flood protection and sustainability. Water International, vol. 27, 2002, pp. 3-13.

[15] Lumbroso D.M., Johnstone W., De Bruijn K.M., Di Mauro M., Lence B., Tagg A.: Modelling mass evacuations to improve the emergency planning for floods in the $U K$, the Netherlands and North America. [in:] International Conference on Emergency Preparedness (InterCEPt), The Challenges of Mass Evacuation, 21-23, Sept 2010, University of Birmingham, UK 2010.

[16] Mooney P., Corcoran P.: The Annotation Process in OpenStreetMap. Transactions in GIS, vol. 16(4), 2012, pp. 561-579. 
[17] Mooney P., Corcoran P., Winstanley A.C.: Towards quality metrics for OpenStreetMap. [in:] Proceedings of the Eighteenth ACM SIGSPATIAL International Conference on Advances in Geographic Information Systems, Seattle, Washington 2010, pp. 514-517.

[18] OSM Map Features 2016 The Map Features Page Guide to Tagging Features on OpenStreetMap. [on-line:] http://wiki.openstreetmap.org/wiki/Map_Features [access: 21.09.2016].

[19] Pel A.J.: Transportation modeling for regional evacuations. TRAIL Research School 2011 [doctoral thesis].

[20] Pel A.J., Bliemer M., Hoogendoorn S.P.: A review on travel behavior modeling in dynamic simulation models for evacuations. Transportation, vol. 6, 2012, pp. 50-62.

[21] Pietrusiewicz W.: Problemy metodyczne opracowywania map dostępności czasowej Polski. Przegląd Kartograficzny, t. 28, nr 2, 1996, pp. 87-99.

[22] Program ochrony środowiska województwa mazowieckiego na lata 2011-2014 z uwzględnieniem perspektywy do 2018 roku. Warszawa 2012.

[23] Rosik P.: Zróżnicowanie dostępności drogowej regionów Polski. Transport Miejski i Regionalny, nr 5, 2008, pp. 2-8.

[24] Rosik P.: Dostępność lądowa przestrzeni Polski w wymiarze europejskim, Prace Geograficzne, nr 233, IGiPZ PAN, Warszawa 2012.

[25] Śleszyński P.: Dostępność czasowa i jej zastosowania. Przegląd Geograficzny, R. 86, z. 2, 2014, pp. 171-215.

[26] Sobczyk W.: Dostępność komunikacyjna w układach osadniczych miast. PWN, Warszawa 1985.

[27] Stępniak M.: Wykorzystanie metody 2SFCA w badaniach dostępności przestrzennej ustug medycznych. Przegląd Geograficzny, t. 85, nr 2, 2013, pp. 199-218.

[28] Strategia rozwoju województwa mazowieckiego do 2030 roku. Załacznik do Uchwaty nr 158/13 Sejmiku Województwa Mazowieckiego z dnia 28 października 2013 r.

[29] Thaler T., Hartmann T.: Justice and flood risk management: reflecting on different approaches to distribute and allocate flood risk management in Europe. Natural Hazards, vol. 83, 2016, pp. 129-147.

[30] Tsakiris G., Nalbantis I., Pistrika A.: Critical Technical Issues on the EU Flood Directive. European Water, vol. 25/26, 2009, pp. 39-51.

[31] Warakomska K.: Zagadnienie dostepności w geografii transportu. Przegląd Geograficzny, t. 64, z. 1-2, 1992, pp. 67-76.

[32] Wiśniewski S.: Dostępność przestrzenna straży pożarnej do miejsc potencjalnych interwencji na terenie województwa łódzkiego. Bezpieczeństwo i Technika Pożarnicza, vol. 43, nr 3, 2016, pp. 21-36.

[33] https://www.mazovia.pl/transport-publiczny/transport-drogowy/) [access: 09.08.2016].

[34] www.mapy.isok.gov.pl [access: 15.07.2016]. 


\section{Dostępność do miejsc ewakuacji dla mieszkańców terenów zagrożonych powodziami w województwie mazowieckim}

Streszczenie: W artykule podjęto próbę określenia dostępności do miejsc ewakuacji z terenów zagrożonych powodzią do najbliższych i osiągalnych obiektów użyteczności publicznej w granicach województwa mazowieckiego przy wykorzystaniu dwuetapowej metody określenia obszarów rynkowych (2SFCA). Za teren zagrożony powodzią przyjęto obszar tzw. wody stuletniej, który został wyznaczony na mapach zagrożenia powodziowego. Dla realizacji celu pracy niezbędne było wykorzystanie danych pochodzących z zasobu BDOT oraz OSM. Stwierdzono, że najgorsza sytuacja pod względem dostępności miejsc do ewakuacji w czasie do 15 minut występuje w południowo-wschodniej części województwa mazowieckiego oraz wzdłuż Bugu i Narwi, czyli tam, gdzie tereny zalewowe są szerokie i znajduje się dużo budynków mieszkalnych.

Słowa

kluczowe: ochrona przed powodzia, ewakuacja, dostępność transportowa, województwo mazowieckie, GIS, tereny zalewowe 